\title{
DISCUSSING ACCULTURATION AS AN INTERPRETIVE MODEL: ROMANISATION AS A CASE-STUDY 1
}

\author{
Pedro Paulo Abreu Funari ${ }^{2}$ \\ Renata Senna Garraffoni ${ }^{3}$
}

\begin{abstract}
The aim of this conference is to discuss how post-colonial approach can help us to rethink Roman identity and the theory of Romanization. The conference explores different theoretical models and focuses in two inter-related topics: first we shall discuss how acculturation model promoted a more homogenous and conservative understanding of the Roman past and then we shall argue how diference and otherness can be an important tool to propose a more heterogeneous approach to the Roman Empire.
\end{abstract}

\section{Keywords}

Roman identity; Romatization; Acculturation.

\section{Resumo}

O objetivo da conferência é discutir como a teoria pós-colonial permite o questionamento das noções de identidade romana e da teoria de Romanização. A conferência explora diferentes modelos teóricos e foca em dois tópicos relacionados: inicialmente discutiremos como o modelo de aculturação promoveu uma explicação homogênea e conservadora do passado romano para, em seguida, argumentar que o estudo da diferença e da alteridade é um instrumento importante para propor modelos mais heterogêneos do Império Romano.

\footnotetext{
${ }^{1}$ Conference. Colóquio - O Império Romano e suas províncias: a integração e seus limites". Museu de Arte de São Paulo, Brazil, March 28-29, 2012.

2 Professor Titular - State University of Campinas, Campinas, Brazil. E-mail: ppfunari@ uol.com.br

3 Associate Professor - Federal University of Paraná, Curitiba, Brazil. E-mail: resenna 93@gmail.com
} 


\section{Palavras chave}

Identidade romana; romanização; aculturação.

Prima di tutto, chiediamo scusa ai nostri colleghi italiani, in maggioranza tra gli stranieri, ma abbiamo scritto in nostro saggio in inglese, cosiché tutti capiranno.

Für Professor Winterling: wir sind sehr glücklig Professor Winterling ist hier heute mit uns, willkommen!

We start by thanking the organizers of the conference on the Roman Empire and its provinces, integration and limits, particularly Doctor Carlos Augusto Ribeiro Machado who invited us to take part in the discussions. It is indeed an honour and a pleasure to learn and discuss such important issues as the interpretation of the Roman world with colleagues such as Attilio Mastino, Maria Isabel Fleming, Guido Clemente, Norberto Guarinello, Paolo Liverani, Aloys Winterling, among others. So, thanks so much. We must also mention from the start that our own stand results from epistemological discussions resulting from our experience in several institutions, from our own universities, Unicamp and UFPR, to UCL, University of Durham, WAC, Barcelona and beyond, often also supported by funding agencies, such as the Brazilian National Science Foundation (CNPq), São Paulo Science Foundation (FAPESP), CAPES, the National Science Foundation, the British Academy among others, so that we must also acknowledge their continued support. This is also the result of dialogue with Richard Hingley and Greg Woolf, among several others ${ }^{4}$. We are though solely responsible for the ideas. Our aim today is to start an epistemological discussion of the theoretical tenets behind Romanisation as an interpretive model and then to show how it has been used and then criticised.

Let's then start with acculturation, by introducing the anthropological discussion on the concept. The model was grounded on the understanding that societies are bounded, homogeneous and stable, whilst people are considered as gregarious and law-abiding. So social norms and rules are taken as accepted by a majority and resisted by those with a deviant behaviour. Those normative models opposed different sets of homogenous entities, first and foremost civilised superior societies, facing inferior and barbarian ones. Acculturation was thus the flux from lower and deviant people towards upper class and

4 Such as André Leonardo Chevitarese, Margarida Maria de Carvalho, Marina Cavicchioli, John Collins, Margarita Díaz-Andreu, Lourdes Conde Feitosa, José Geraldo Costa Grillo, Norberto Luiz Guarinello, Martin Hall, Siân Jones, Jonas Machado, Júlio César Magalhães de Oliveira, Paulo Nogueira, Lluís Pons Haroldo Reimer, José Remesal, Monica Selvatici, Glaydson José da Silva and Thomas Skidmore. 
behaved elites, in a process of passage from a lower setting to a superior one. This scheme applied to dominant Western societies was also applied to the relations between colonial powers and the subjected peripheral societies, so that Barbarians would emulate superior colonial rulers (Hingley, 1985).

Acculturation is thus at the root of all those conservative tenets, conservative as they stress stability, reproduction and emulation (Webster, 2001). Recognizing the importance of the study of acculturation, and the varying points of view from which the problem has been approached, the Social Science Research Council (USA), early 1935, appointed a Committee to analyse the work on the problem already done, to study the implications of the term "acculturation," and to explore new leads for further investigation. After a number of meetings, an outline was drawn up as a first step toward clarifying the problem and to serve as an aid in the classification of studies already made (Redfield, Linton, Herskovits, 1936: 152), concluding with the following possible outcomes when different people interact:

"The results of acculturation:

A. Acceptance: where the process of acculturation eventuates in the taking over of the greater portion of another culture and the loss of most of the older cultural heritage; with acquiescence on the part of the members of the accepting group, and, as a result, assimilation by them not only to the behaviour patterns but to the inner values of the culture with which they have come into contact.

B. Adaptation: where both original and foreign traits are combined so as to produce a smoothly functioning cultural whole which is actually an historic mosaic; with either a reworking of the patterns of the two cultures into a harmonious meaningful whole to the individuals concerned, or the retention of a series of more or less conflicting attitudes and points of view which are reconciled in everyday life as specific occasions arise.

C. Reaction: where because of oppression, or because of the unforeseen results of the acceptance of foreign traits, contra-acculturative movements arise; these maintaining their psychological force (a) as compensations for an imposed or assumed inferiority, or (b) through the prestige which a return to older pre-acculturative conditions may bring to those participating in such a movement".

The key words are assimilation (becoming something else), harmonious whole and retention of traits reconciled (homogeneity and stable) and inferiority and reaction (deviant behaviour by inferiors). These concepts, even though exposed as anthropological tenets in the 1930s, were rooted in much deeper 19th c. social realities and scholarly debate (Díaz-Andreu, 2007). First and foremost, all of them were proposed as the main pillars of the recently created 
nation state: assimilation of everybody into a unit (such as Jewish people, to be accepted and emancipated, so long as assimilated); the nation as a harmonious whole (ein Land, ein Volk, eine Sprache, "one land, one people and one language", the famous slogan of the nation state; cf. Thiesse, 2001; Grosby, 2005); and inferiority and reaction by ordinary people and colonised subjects.

There has been a consistent criticism of those tenets by social movements for a long time. Anarchists, communists, socialists, suffragettes, feminists, civil right activists, gay and religious libertarians all challenged homogeneity, the dichotomies of superior and inferior, civilised and barbarian, and more so the concept of deviation (Funari, Jones, Hall 1999). These have been wide ranging social movements reshaping the way social theory tried to understand society as a heterogeneous and conflicting entity. How to interpret conflict in society depends directly on how we understand society itself. Traditionally, normative models considered that cultures are neatly bounded homogeneous entities (Mullins, 1999:32). This idea is related to the well-known and by now classic definition created by Childe (1935:198): "Culture is a social heritage; it corresponds to a community sharing common institutions and a common way of life [emphasis added]". This definition implies harmony and unity within society, a commonality of interest and thus a lack of conflict (Jones, 1997:15-26). The roots of this understanding of social life lies on the one hand with Aristotle and his definition of society as a koinonia, that is, as a partnership (cf. Aristotle, Politica 1252a7). Sharing values in a homogeneous culture means accepting generalizing features and common traits shared by everybody (cf. Aristotle, Politica 1328a21).

Homogeneity furthermore is a concept informed by capitalist nationalist movements (Handler 1988). Cultures and nations were seen by bourgeois ideology as bounded, unified entities, and history was conceived as the product of the actions and events associated with such homogeneous entities. In this context, generalizing implies homogenizing, and there is a growing dissatisfaction with using this normative approach to interpret social life (cf. Skidmore, 1993:382). The holistic, monolithic nature of cultures and societies has been questioned by several empirical and theoretical studies in the last decades (Bentley, 1987; Jones 1997a). Homogeneity, order, and boundedness, have been associated to a priori assumption that stability characterizes societies, rather than conflict. However, a growing body of evidence and critical scrutiny of social thought has challenged this traditional view, considering society as heterogeneous, with often-conflicting constructions of cultural identity. Heterogeneity, fluidity and continuous change imply also that there are multiple entities that often change within society.

All the normative tenets behind such concepts as Hellenisation and Romanisation were applied to the ancient world in modern imperial projects (cf. Pons, 
2012). In the recent decades though, normative models criticised by social movements first and intellectuals as a consequence questioned the way the ancient world was perceived. This postcolonial and postmodern criticism of those conservative tenets has led to new understandings of modern and ancient societies, considered as heterogeneous, conflictive and diverse, with fluid social relations and interactions. Concepts such as creolisation, hybridism and métissage all stress a mix state of constant interaction and exchange. The study of the ancient world responded to all that with an implosion of most of traditional normative tenets, exploring aspects of social life such as the use of different languages at the same time, the tensions between different religious and ethnic identities, among a long series of subjects exploring diversity, instead of homogeneity, such as patronage (Clemente, 1972), oral traditions (Liverani, 2006), food and supplies (Remesal, 2011).

Recognised that "there was no uniform 'Romaness'", as put recently Danijel Dzino (2011: 60), Jane Webster's (2001: 223) early comments of over a decade ago are worth quoting at length, when she proposed to use creolisation to a less restrictive understanding of ancient Rome:

"the inadequacies of Romanization as a model for contact and culture change in the Roman provinces become increasingly apparent and this acculturative model should be discarded in favour of the concept of creolization... it is time to shift from elites, on whom so much work has focused, to other social categories: the urban poor, the rural poor, and that technically most invisible of social groups in the ancient world, the enslaved"

The use of analogies with modern situations has spread, as attests a recent paper by Leyla Çaglar (2011: 136), also worth quoting:

"The argument that the research of Roman Creolization should be based on studies of the everyday material culture, which entails artefacts such as pots, clay pipes, recipes etc., shows some parallels with the way the emergence of Creole cultures in the Americas is studied".

As we argue in a just published paper (Garraffoni and Funari, 2012), focusing on the excluded past in an effort to accept the existence of denied views of Roman history and archaeology can become a useful political tool to challenge traditional historiography and also to normative interpretations of society today. As put Aloys Winterling (2009: 1), "concepts not of unit but of difference are required". The study of excluded groups in Ancient Rome, through a critical theoretical approach, helps us to challenge the elite views and allows us to seek for a social and political engagement to consider neglected histories in past and present (Silva and Feitosa, 2009). Diversity, resistance and indigenous specificities as puts Attilio Mastino (1993: 458) on Sardegna during Roman times: 
"L'isola ha mantenuto una forte tradizione indigena legata alla civiltà dei nuraghi: civiltà evoluta ma analfabeta, almeno allo stato della documentazione attuale, per quanto non manchino le segnalazioni, fin qui non sufficientemente chiarite, di iscrizioni riferite genericamente ad età nuragica, con espressioni del sostrato paleosardo".

"The island kept a strong native tradition linked to the civilization of the nuraghi: a developed civilization but illiterate, considering the documents available today, even if there are traces, not clear enough, of inscriptions of the nuragic period, expressing an old Sardinian layer" (our translation).

Influxes from peripheral situations as those in Latin America are clear in that direction, as studies on gender (Feitosa, 2004; Cavicchioli, 2008; Reimer, 2009), sexuality (Garraffoni, 2010), violence and resistance (Grillo, Garraffoni and Funari, 2011) poor and excluded people indicate (Funari, 1993; Magalhães de Oliveira, 2006), slavery (Joly, 2005) contributing to the broadening of the role of ancient history to modern issues (Carvalho and Funari, 2007). The same applies also to issues relating to religious identities and conflicts (Guerra et alii 2003; Selvatici, 2008; Chevitarese and Cornelli, 2009; Machado, 2010; Nogueira, Funari, Collins, 2010; Carlan, 2011), parataxis (Martins 2010). A peripheral outlook has proved productive (Guarinello, 2008).

Paying homage to our Italian colleagues, it is perhaps particularly appropriate to conclude this brief essay by quoting Salvatore Settis (2006: 110), as he proposes that Roman studies can be "an effective key for accessing the multiplicity of cultures in the modern world and for the help it can give us understanding the way in which these cultures are penetrating each other".

Thank you so much for your patience.

\section{References}

Bentley, G.C. "Ethnicity and Practice". Comparative Studies in Society and History 29, 1987, 24-55.

ÇAGLAR, L.R. Romanisation or no romanisation, that is the question of socio-linguistic in the Roman Empire, Synergies Turquie, 4, 2011, 131-138.

CARLAN, C.U. Coins and power in Rome: political ideology in the 4th century.. In: David Hernández de la Fuente (Org.). News perspectives on late Antiquity.. 1 ed. Cambridge: Cambridge Scholars Publishing, 2011, v. 1, p. 150-157. 
CARVALHO, M.M.; FUNARI, P.P.A. Os avanços da história antiga no Brasil: algumas ponderações, História, 26, 1, 2007, 14-19.

CAVICCHIOLI, M.R. The erotic collection of Pompeii: archaeology, identity, and sexuality. In: Funari, P.P.A.; Garraffoni, R.; Letalien, Bethany (Org.). New perspective on the Ancient World. modern perceptions, ancient representations. Oxford: Archeopress, v. 1782, 2008: 187-194.

CHEVITARESE, A.L.; CORNELLI, G. Religious syncretism in Mediterranean Hellenistic culture. Revista de Estudos sobre o Jesus Histórico e sua Recepção, v. ano 2, p. 1-10, 2009.

CHILDE, V.G. (1935). "Changing methods and aims in Prehistory", Presidential Address for 1935. Proceedings of the Prehistoric Society 1:1-15.

CLEMENTE, G."II patronato nei collegia dell'Impero Romano", Studi classici e orientali 21 (1972), 142-229.

DÍAZ-ANDREU, M. A world history of nineenth-century archaeology, Oxford, Oxford University Press, 2007.

DZINO, D. Becoming Slav, becoming Croat, Identity transformations in Post-Roman and early medieval Dalmatia. Leiden, Brill, 2011.

FEITOSA, L.M.G.C. Amor y sexualidad en el universo popular pompeyano. Revista Habis, Sevilla, v. 35, 2004: 285-290.

FUNARI, P.P.A. Graphic caricature and the ethos of ordinary people at Pompeii. European Journal of Archaeology, v. 1, n. 2, p. 133-150, 1993.

FUNARI, P.P.A.; Jones S. \& Hall, M. Introduction: archaeology in history, in P.P.A FUNARI, M. Hall \& S. Jones (eds), Historical archaeology, back from the edge, Londres, Routledge, 1-20, 1999.

GARRAFFONI, R.S. Via del Lupanar em Pompéia: contribuições da arqueologia para repensar política e sexualidade no mundo romano. In: OLIVEIRA, T. (Org.). História e historiografia da educação nos clássicos: estudos sobre Antiguidade e Medievo. Dourados: UEMS, 2010: 57-71.

GARRAFFONI, R.S.; FUNARI, P.P.A. The uses of Roman heritage in Brazil: traditional reception and new critical approaches, Heritage and Society, 5, 1, 2012.

GRILLO, J.G.C. (Org.); GARRAFFONI, R.S. (Org.); FUNARI, P.P.A. (Org.). Sexo e violência: realidades antigas e questões contemporâneas. 1. ed. São Paulo: Annablume; FAPESP, 2011. v. 1. 283 p. 
GROSBY, S. (2005) Nationalism. Oxford, Oxford University Press.

GUARINELLO, N.L. A Morphology of Ancient History from a tropical, half-European viewpoint. In: Pedro Funari; Renata Garrafoni; Bethany Letalien. (Org.). New perspectives on the ancient world. 1 ed. Oxford: Archeopress, 2008, v. 1, p. 1-248.

GUERRA, A.; SCHATTNER, T.; FABIÃO, C.; ALMEIDA, R. Nova investigações no santuário de Endovélico (S. Miguel da Mota, Alandroal): a campanha de 2002, Revista Portuguesa de Arqueologia, 6, 2, 2003, 415-479.

HANDLER, R. (1988). Nationalism and politics of culture in Quebec. University of Wisconsin Press. Madison.

HINGLEY, R. (2005) Globalizing Roman culture. Unity, diversity and empire, London: Routledge.

JOLY, F.D. A escravidão na Roma antiga: política, economia e cultura. 1. ed. São Paulo: Alameda, 2005.

JONES, S. "Nationalism, archaeology and the interpretation of ethnicity in ancient Palestine". Boletim do CPA 3, 1997, 49-80. Campinas. Brazil.

JONES, S. The Archaeology of ethnicity. Constructing identities in the past and present. London: Routledge: 1997a.

LIVERANI, P. Immagine, scrittura e oralità, in I. Colpo - I. Favaretto - F. Ghedini (a cura di), Iconografia 2005. Immagini e immaginari dall'antichità classica al mondo moderno (Atti del Convegno Internazionale, Venezia, 26-28 gennaio 2005), Quasar, Roma, 2006, pp. 261-266.

MACHADO, C. Roman aristocrats and the christianization of Rome. In: Brown, P.R.L.; Lizzi Testa, R.. (Org.). Pagans and Christians in the Roman Empire: the breaking of a dialogue (IVth-VIth Century A.D.). Proceedings of the International Conference at the Monastery of Bose (20-22 October 2008), (Christianity and History, 9). Münster: LIT Verlag, 2011, v., p. 493-516.

MACHADO, Jonas. Identidade paulina em construção: de Saul o fariseu a Paulo o apóstolo de Jesus Cristo. In: Paulo Augusto de Souza Nogueira; Pedro Paulo A. Funari; John J. Collins. (Org.). Identidades fluídas no judaísmo antigo e no cristianismo primitivo. $1^{\text {a }}$ ed. São Paulo: Annablume/Fapesp, 2010, v. 1, p. 283-329.

MAGALHÃES DE OLIVEIRA, J.C. “Vt maiores pagani non sint!" Pouvoir, iconoclasme et action populaire à Carthage au début du Ve siècle (Saint Au- 
gustin, sermons 24, 279 et Morin 1). Antiquité tardive: revue internationale d'histoire et d'archéologie (IVe-VIIIe s.), v. 14, p. 245-262, 2006.

MARTINS, P. Parataxe e Imagines. Revista de Estudos Filosóficos e Históricos da Antiguidade, v. 24/25, p. 141-175, 2010.

MASTINO, A. Analfabetismo e resistenza: Geografia epigrafica della Sardegna, In: Calbi, Alda; Donati, Angela; Poma, Gabriella (a cura di). L'epigrafia del villaggio. Faenza, Fratelli Lega Editori. p. 457-536, 1993. (Epigrafia e antichità, 12).

MULLINS, P.R. (1999). Race and affluence. An archaeology of African America and consumer culture. Kluwer/Plenum. New York.

NOGUEIRA, P.; Funari, P.P.A. (Org.); Collins, J.J. (Org.). Identidades fluídas no judaísmo antigo e no cristianismo primitivo. São Paulo: AnnaBlume/FAPESP, 2010. v. 01. 345 p.

PONS, L. quae sunt Caesaris, Caesari, et quae sunt Dei, Deo (Mt. 22, 21). El imperio colonial francés en el norte de África y la recogida de datos arqueológicos, Visions de l'Occident Romain, Paris, De Boccard, 2012, 308-320.

REDFIELD, R.; LINTON, R.; HERSKOVITS, M.J. Memorandum for the study of acculturation, merican Anthropologist, New Series, Vol. 38, No. 1 (Jan.-Mar. 1936), pp. 149-152.

REIMER, H. Dialogue and feminin: about two absences in Luke 15,11-32. In: Christina Duncker; Katrin Keita. (Org.). Lieblingsfrauen der Bibel und der Welt. Norderstedt: BOD, 2009, v., p. 152-159.

REMESAL, J. Producción y consume de vino y salazones en la España romana, Blázquez Martínez, JMa ; Historia económica de España en la antigüedad, Madrid, 2011, 193-231.

SELVATICI, M. Ethnicity and ancient Judaism: Jewish identities in $1^{\text {st }}$ century Alexandria and Antioch. In: Pedro Paulo Funari; Renata S. Garraffoni; Bethany Letalien (Org.). New Pespectives on the Ancient World: modern perceptions, ancient representations. Oxford: Archaeopress, 2008, v., p. 213-220.

SETTIS, S. The future of the 'classical'. Cambridge: Polity Press, 2006.

SILVA, G.J. FEITOSA, L.M.G.C. O mundo antigo sob lentes contemporâneas. In: Funari, P.P.A., Silva, M.A.O. (eds). Política e identidades no mundo antigo. São Paulo: Annablume, 2009: 209-250.

SKIDMORE, T. (1993). Black into white: race and nationality in Brazilian thought. Durham, London. Duke UP. 
THIESSE, A.M. La création des identités nationales, Europe XVIIIe.-Xxe. siècles (Paris, Éditions du Seuil, 2001).

WEBSTER, J. Creolizing the Roman provinces, American Journal of Archaeology, 105, 2, 2001, 209-225.

WINTERLING, A. Politics and society in ancient Rome. Chichester, Willey, 2009. 